\title{
4 Established and emerging actors in the national political arenas
}

\author{
Jaakko Kauko, Olli Suominen, Vera Gorodski \\ Centeno, Nelli Piattoeva, and Tuomas Takala
}

\section{Introduction}

Our book's key questions concern how agendas and actors' arenas interact. In analysing the policy process, Baumgartner and Jones observe that political change happens in ruptures after the agenda is changed by growing positive, change-supporting feedback, such as diffusion from other political systems, which catalyses change in the political sub-system's arrangement (Baumgartner \& Jones 2009). An analysis of this in relation to quality assurance and evaluation (QAE) is of interest to our research.

We can identify a transnational QAE agenda. As we pointed out in Chapter 1, instead of looking at all the contents of this QAE "megatrend" (Vedung 2003: p. 1), we focus on how the integration of global education policy discourses and practices and the general interest in measuring quality in education have changed and reshaped the actor relations within a polity. For example, there is evidence of the effects of QAE on the roles of national education policy actors in how information and data have provided the means for an attempt to regain central power (Ozga et al. 2011) while simultaneously, and somewhat paradoxically, creating an image of a more decentralised, horizontal, and networked understanding of knowledge (Ozga 2012). To reiterate Chapter 1's idea, it is only when a slippery and undefinable notion of quality is applied that the QAE agenda starts to affect the national political arena. For example, new organisations responsible for large-scale assessments are introduced, leading to a rearranging of the existing organisations' roles.

When a rupture of the status quo happens, " $[\mathrm{t}]$ he old policymaking institutions find themselves replaced or in competition with new bodies that favor different policy proposals" (Baumgartner \& Jones 2009: p. 4). Central to the understanding of these dynamics is the analysis of sub-systems such as the education system and the possible QAE expert communities which exist within it. Baumgartner and Jones discuss "policy monopolies" which have an institutional structure connected to policymaking and exclusive access to expertise and which legitimise their action with the help of core political values such as fairness or economic growth. These monopolies can be disturbed, for example, with the help of agenda-setting through the media, whereas apathy helps 
to sustain a monopoly (Baumgartner \& Jones 2009). We assume that QAE expert communities meet this definition. QAE policy meets this characterisation in terms of exclusion through expertise and the core political values of enhancing learning and economic growth. In our research, we are interested in understanding the extent to which the potential positive, change-supporting feedback on the agendas of these three countries has resulted in a change in polity.

Using the CADEP terminology adopted in Chapter 1, this chapter starts an analysis of the political constellations of actor, that is, the political situation. We demonstrate that the political constellation of actors is inseparable from changes in the second dimension of CADEP, namely the political possibilities. In attempting to understand the relationship between these two dimensions, we use the idea of Baumgartner and Jones (2009), who claim that policy agendas and the structure of the political system are interconnected. Distinguishing the relevant actors is also connected with the idea of what is on the agenda. Our primary focus is on structural change, but we also link this to the changing QAE agenda. We aim to analyse the changing national political situation in Brazil, China, and Russia in relation to the possibilities and restrictions created by the effort to measure and improve the quality of school education.

Using the data presented in Chapter 2, this chapter focuses on documentary and interview data from individual actors - the international and key national organisations involved in QAE policy and practice in the three countries. We focus on interviews at international and national levels. These interviews and documents largely sourced online limit our empirical interest to developments since the turn of the millennium.

Although all three countries have a history of suspicion to various degrees towards international actors, since at least the 1990s, they have become increasingly involved in international cooperation in the field of education quality and its evaluation, which means that many actor relations and agendas are also transnationally linked. To understand the changing constellations of actors in QAE policy, our analysis focuses on two dynamics. The first relates to how the development of expert communities is networked transnationally to international actors, the second to how the changing polity has activated other actors.

\section{Building national QAE education policy communities}

The development of QAE capacity and tools in Brazil, China, and Russia is also connected to external advice from international organisations. However, the timing and extension has varied in each case. In line with our theory, the technical side of large-scale assessment is a reflection of actor relations. As we pointed out in the book's introduction, the question of handling, designing, and planning data use is political, and it therefore makes sense for national governments to develop their capacity. Where the interconnectedness of agendas with actor relations is concerned, we observe that agendas slowly began to adopt QAE ideas in the 1990 s and that its feedback resulted in different degrees 
of polity reorganisation. In each context, the development of national expert communities is tightly linked to financial resources and political decisions.

\section{The changing agenda in the 1990 s}

During the 1990s, in all countries, the international and transnational influences of QAE began to make an impact. The international community affected this in two ways: through direct recommendations from international organisations, especially the World Bank, and through the influence of the internationally networked expert community. In each context, the mix varied.

In Brazil, there was a gradual accumulation of national expert networks and their capacity in parallel with international organisations' involvement. Brazil differs from Russia and China in its longer-term cooperation with the Organisation of American States, the US American Aid Institution (USAID), the United Nations Educational, Scientific and Cultural Organisation (UNESCO), and the World Bank, among others, which has been a reality since World War II. A research article from our project concluded:

Education-indicator programmes have blossomed since the 1990s, alongside global education-related IO [international organisation] programmes. Independently of their political position, all the post-dictatorship governments took steps towards implementing assessment with a view to improving quality in education, a strategy that mirrored global developments. In this development, we have pointed out the importance of the long buildup of QAE capacity and webs of experts.

(Kauko et al. 2016)

China's engagement with the international community began in earnest only in the post-Mao period, and it was not until the 1980s that China joined the entire network of intergovernmental organisations (IGOs) (Kent 2002; Ngok \& Kwong 2003). By the 1990s, China's policy of opening to the world had increasingly exposed the Chinese education community to new foreign ideas, and international education issues had noticeably surfaced. Journals increasingly dealt with the subject, and the first government research units were established (Altbach 1991). Various IGOs, such as UNESCO, through its global Education for All movement, the World Bank, the OECD, and the European Union also became increasingly active in promoting transnational education practices and programmes in China (Ngok \& Kwong 2003; Suominen et al. 2017). By the mid-1990s, many international non-governmental organisations (INGOs) had also begun to launch projects and establish offices in the country (Ma 2002; Deng 2010; Yang G. 2005).

As Chapter 3 described, simultaneously, and partly resulting from these international contacts, the Chinese education system had also begun to shift from quantitative to qualitative targets to boost the state's modernisation drive. Many reformers who advocated these ideas, later known in the Chinese 
discourse as "quality education", were familiar with Western education theory, and the North American notion of "competency-based education", emphasising specific competencies instead of exam success, was especially popular (Kipnis 2006).

This shift in priorities also required the development of a national QAE capacity. International experience and practice were especially influential in the construction of the national assessment system (Zhang \& Wan 2017). An interviewee explained, "As a matter of fact, it [the establishment of the assessment system] is also a reply to the demands of globalisation. So, against a backdrop like this, we also wanted to understand what the current situation of Chinese education was like" (CN-E-02). The OECD's Programme for International Student Assessment (PISA) surveys' strong influence on the development of this national assessment system is acknowledged by practitioners and academics alike (the assessment has even been called the "Chinese PISA" - a formulation used by many of our interviewees), although direct borrowing has occurred mainly in technical areas.

In post-Soviet Russia, international organisations gained some prominence between the mid-1990s and mid-2000s. In this period's early years, in a bilateral Dutch-Russian project, the World Bank and the OECD prepared reports on Russian education. These reports were diplomatic enough to give credit to the achievements of the Russian education system during the Soviet period, but the basic message was one of strong criticism of the traditional Russian notion of what constituted quality education (Leonteva, Plomp, \& Voogt 1998; World Bank 1995; OECD 1998). This pedagogical tradition was criticised as unsuitable for the needs of a market economy, and a new system of assessment was recommended as a tool for changing the mode of learning, examinations, incentivisation, and information gathering. As evidence for this argument, reference was made to the low performance of Russian students in PISA, in sharp contrast with their excellent performance in the Trends in International Mathematics and Science Study (TIMSS) and Progress in International Reading Literacy Study (PIRLS) tests. However, these recommendations resonated with the views of a reform-minded faction of Russian policymakers and education experts, and it is impossible to demonstrate a causal effect between the two. Yet very few QAE reforms took off at the national level during this period, apart from the piloting of the national school-leaving examination.

In the late 1990s and early 2000s, most changes in Russia were first implemented at the sub-national level, channelled through World Bank-funded project work in selected pilot regions. During this period, many assessment consultants travelled to Russia to promote their views on appropriate policy and practice, typically with very little knowledge and understanding of the existing baseline situation. Our interviews indicate that Russian experts considered much of the advice patronising and inflexible. Nevertheless, after this troubled start, gradual processes of dialogue followed. In the Republic of Chuvashia, where we conducted our fieldwork, the World Bank-funded project (operational between 2002 and 2006) was generally regarded by our interviewees as having produced lasting results in capacity building, and the same is 
acknowledged of the bank's Project Completion Report (World Bank 2007). One of our interviewees, who has held a prominent administrative position, described this process as follows:

Everything was new for us, so our views did not mean much, while they [the international experts] had seen a lot, and there were a lot of compromises in the discussion and defence phases [of the proposed projects] ... Sometimes it [discussion on the intermediary reports] got really crazy. Either the experts or our people would cry because of the misunderstandings or tough approach to a position if you couldn't prove it, even if you were absolutely convinced you were right. So, they were very rigorous discussions, very deep ones.

(RU-E-15)

This aptly describes the general influence in all cases: data expertise is an appealing argument for national steering and guidance. Each of the countries' expert networks were engaged in dialogue.

The agenda in each country therefore evolved during the 1990s to support the idea of QAE in education governance. This began to bear fruit in conjunction with the changing financial and political situation during the new millennium and eventually affected the political constellation of actors.

\section{Building capacity}

The extent to which Brazil, China, and Russia have worked with international organisations varies, and the nature of cooperation seems to depend on their respective financial and political situations.

At the turn of the twenty-first century the World Bank became more active in Brazil (Kauko et al. 2016). However, its focus has shifted, as none of the twenty-five projects between 2003 and 2016 operated on the national level (World Bank 2016). Indeed, the Brazilian interviewees described how international organisations had redirected their activity towards sub-national actors, because the national level had developed capacity and funding independence and had different political motives. A new QAE policy expertise started to take shape with the help of independent analysis, greater independence in funding, and increased political independence, which eventually changed polity.

Brazil appears to have attained a national capacity for independent data analysis in the 2000s, meaning that international organisations' technical assistance was no longer needed. Indeed, Brazilian governments had implemented largescale assessments in the 1990s. Interviewees from different branches of an international organisation discussed this shift to working with sub-national instead of national actors:

We haven't had the dialogue at the federal level that we would like in the past five or six years, but we've been very active at the state level.

(BR-IGO-01) 
Here in Brazil, fifteen years ago, we were doing education projects at the federal level ... We don't do that any longer. They don't need us.

(BR-IGO-02)

Besides the development of national capacity, the international loaning organisations, the World Bank and the Inter-American Development Bank (BID), pointed to funding independence at the federal level as one of the main reasons for the change of focus to the sub-national level. Indeed, whereas some interviewees pointed to the strong national capacity emanating from the National Institute for Educational Studies and Research (INEP: the office responsible for large-scale assessments), the international organisations did not trust the implementation capacity of all the Brazilian states. Unlike the federal government, they felt financially strapped states and municipal level governments especially needed both financial and technical advice.

In terms of financing the federal level doesn't need [name of an international organisation]'s financing. This is different from twenty or twentyfive years ago. The state and municipal levels still need financing.

(BR-IGO-02)

Basically, one of my first impressions when I came to the [IGO] was that obviously you want to help the poorest states.

(BR-IGO-06)

The need and potential for political independence at the federal level seems also to have been behind the international organisations' new sub-national activity. A Ministry of Education representative pointed out that international organisations like the OECD and the World Bank struggled to understand Brazil's complexity, making them less attractive partners.

I would love to work with anyone who can understand that we are very diverse and there is no magic solution for anything ... If the World Bank or the OECD could understand this I would be happy to work with them ... If the World Bank wants to do this, I'm a partner.

(BR-N-10)

A representative of an international organisation noted that ministers were perhaps unhappy with some of the results of their reports.

I'm not sure, but maybe the last ministers did not agree with the evidence that the [international organisation] supports. Maybe.

(BR-IGO-03)

This political stance is further visible in the different emphases of international organisation and Ministry of Education interviewees concerning whom the states should consult in their technical work. The former emphasised 
international organisations' technical expertise, whereas the latter saw universities as suitable partners.

I think that sometimes one of the things that [international organisation] is doing is helping some of the states, as we have done in Rio, to strengthen the statistical and planning units within the secretariats so they can be more effective.

(BR-IGO-06)

We have to evolve to a model of more partnership so the universities play the most important role, and the states and cities of course don't have many technical people to work with us: we have to make an effort to understand why they need something, and the university can provide these services better than they can.

$(\mathrm{BR}-\mathrm{N}-10)$

The changes in the Brazilian political arena indicate the gradual accumulation of national QAE policy expertise and the way in which this has sidelined international organisations at the national level. Financial capacity and the potential for using knowledge are essential in the quest to become a relevant actor in the Brazilian system. The interviewees describe how the national government's dependence on international expertise diminished after it had succeeded in developing financial and technical QAE resources. In Brazil, QAE thus appears to be related not only to technical and financial but also to political independence.

In China, the development of expertise is advanced, but there is also some caution concerning outside political influence. The events of 1989 proved a turning point, after which China became more reserved about foreign education patterns (Altbach 1991). China remains ambivalent about international cooperation because it is seen as presenting a potential threat to the party-state's sovereignty (Kent 2002). Although education issues are not especially sensitive in China, in recent years, the government has become especially cautious about INGOs operating in China (Yin 2009; Hsia \& White III 2002). As Yin (2009: p. 534) argues, "While recognizing the potential contributions of foreign NGOs, the Chinese government is also becoming increasingly wary of the growing presence of foreign NGOs in the country and has warned against the 'potential national threat' that they may pose." Our interviewees also confirmed this increasing suspicion, although they did not elaborate why this had been the case either with their organisations or the education field in general. Using Baumgartner and Jones's concepts, it is clear Chinese policy seeks to maintain apathy regarding assessments.

Of course, none of this is to say that internationally focused work has had no impact on China. First, the country has been influenced by personal experiences and contacts. The assessment system especially, as has been mentioned, is largely staffed by people familiar with foreign practice who have been involved in extensive exchanges of ideas. For example, there has been cooperation at workshops, lectures, and consultations with people working with the OECD's 
Teaching and Learning International Survey (TALIS), the Educational Testing Service, and the International Association for the Evaluation of Educational Achievement. Foreign scholars also increasingly travel to China as guest speakers and visiting scholars.

Second, there have also been more direct contacts. IGOs are directly consulted, for example, when national education reform plans are drafted to assist in their incorporation into China's international commitments. UN agencies seem especially to be in a position in which they are seen - as one interviewee (CN-IGO-01) put it - as more "governmental" and are thus consulted at an even earlier stage of policy formulation than previously. Most recently, the OECD, with the World Bank and other IGOs, participated in the preparation of the National Guidelines for Medium- and Long-Term Educational Reform and Development, which outlines the future development of education for 2010 until 2020 ( $\mathrm{Gu} 2010$ ). Our interviews confirmed this also applies to the next development plan, which extends to 2030 and is under construction. However, because the Chinese government has had a quite straightforward vision of what counts as quality in education, IGOs' consultative role is primarily to plug the gaps beyond the room for state action which the national QAE systems do not cover. In implementing their own programmes, IGOs need to align their goals to meet the goals of national reform programmes. In addition to IGOs, both semi-governmental and non-governmental international development aid organisations (we refer to all these actors as INGOs) have been active in China. The Chinese state does not allow INGOs to operate independently. They are required to work with local state education bureaus. Moreover, except in cases where support is limited to the provision of funding, INGOs can only operate on sub-national levels, that is, with provincial, county, city, or school-level actors, and they align their development goals and plans with national plans. The role of INGOs has also been restricted to ensure quality beyond the room for state action - much as is the case with IGOs but to an even greater extent and INGOs have thus focused on issues such as sex education and education for disabled children. These notions of quality beyond the room of the state are also reflected in the data used to ensure quality (CN-IGO-01).

IGO representatives, however, fully acknowledge that they lack the state's capacity in data gathering:

I think, of course, we may not do [as] well ... as [state] research institutes in terms of building the evidence. That's where we have to learn.

(CN-IGO-04)

The nature of international experts' roles and communication with them has changed in Russia. No large international organisation currently holds a visible position in Russia, and the World Bank no longer contributes to Russian education reforms. Much as in China, it could also be said that testing as one element of QAE has been more influenced by cooperation with specialised agencies (e.g., ETS, CITO, or Cambridge Assessment) and individual experts 
than by any large-scale, externally funded education reform. However, cooperation still occurs in the context of the transnational QAE agenda outlined in Chapter 1. Russian experts and civil servants participate in various international activities at their own initiative. Currently, cooperation with international actors seems to happen mostly around the international learning tests (PISA, PIRLS, and TIMSS), as the Russian experts who administer and analyse these data have become members of executive boards or subject committees and/or participate in international conferences and meetings of assessment specialists and researchers. However, these tests are not understood as changing the system in a top-down manner:

Interviewer (I): $\quad$ So, the reorientation took place under the influence of participation in international assessment. Or is participation in these assessments the result?

Respondent $(R)$ : Reorientation did not happen for this reason; it took place because schools in our country started to change ... We can't say the Russian school started to teach children to apply knowledge because of international surveys. No, that would be a complete lie. The truth is that schools started to change. We ourselves understood what was important, that children should not learn by heart, and need to apply what they learn more. Because our economy is changing, it is becoming integrated into the world and so on. And only on this basis do we take part in surveys which compare us on the basis of criteria we understand (RU-E-12).

In all three contexts, the transnational agenda for the production of data has affected the national polity. In Brazil, increasing capacity has resulted in less dependency on data and resources provided by international organisations. In China, international organisations never gained a strong position in the provision of data or resources but were instead confined to indirectly influencing decision-makers and focusing more directly on issues deemed marginal in the drive for education reform. In Russia, international organisations' role is less than it was in the mid-2000s. The change in QAE agendas has therefore led to the development of national QAE expert communities which rebalance state actors' roles (this redefinition of state and expertise is analysed more thoroughly in Chapter 5). In this process, national governments have enhanced their data analysis capacity to meet the level of international organisations. At the same time, data experts have gained more autonomy. Nevertheless, international organisations have been increasingly sidelined as national capacity has grown.

\section{New actors}

In the previous section, we described how QAE actor constellations were redefined following a change in national agendas. This has affected polity, as it has 
changed the role of other actors in each of the countries. All have witnessed the growing importance of organisations responsible for large-scale assessments, which we address in more detail in Chapter 5 . There are also varying degrees to which the different actors - sub-national governments, international and intergovernmental organisations, and national and local non-governmental actors (non-profit organisations, commercial companies, professional networks) - find room for action with the help of claims for data expertise.

Our analysis shows that the intertwining of changing agendas and actor constellations is visible in how QAE expertise and capacity are essential to justify who may belong to the expert community. This is true of all our case countries, even though they have quite different governance structures. In Brazil, China, and Russia, new expert agencies responsible for conducting large-scale assessments have been established. It is also of interest that we can observe other emerging actors such as third-sector movements (Brazil), think tanks (China), and fluid expert networks (Russia), reshaping the education-political landscape. However, these attempts of unofficial non-governmental or semi-governmental (China) organisations to gain greater prominence in decision-making with the help of QAE expertise do not always succeed.

\section{Brazil: ascendancy of civic movements}

NGOs in Brazil are well networked with both public and private actors at the national and international levels: they occupy a firm position as part of the QAE policy actor constellation. QAE policy and practice have shaped and fed their agendas, which are closely related to government QAE policy and practice.

Social movement organisations, such as Campanha Nacional pelo direito à Educação (Campanha: the Brazilian Campaign for the Right to Education) and Todos pela Educação (TPE: All for Education), function as major platforms and have a decisive impact on policymaking (see Centeno, Kauko, \& Candido 2017). These NGOs bring together almost every actor, national and international, and public and private, and therefore possess significant legitimacy. Furthermore, they both exert their influence by lobbying government and producing studies, proposals, and activities, as well as by networking and cooperating with major national public actors like the INEP and the Ministry of Education and international and national organisations.

QAE has paved the way, either triggering or making possible their involvement and positioning in the education arena, both in terms of knowledge production and policymaking. As one interviewee explains:

[T] here are several social actors which had faded a little [from the development of QAE] and [others] which were not organised [but] which emerged with that movement [of large-scale assessment], particularly Todos pela Educação which was the social framework of legitimisation for the Haddad [Minister of Education] project [of the large-scale assessment indicator, IDEB.] A Campanha ... which is the bigger [social] movement ... didn't 
have [large-scale] evaluation on its agenda at that time ... [It has] taken [it] a long time to construct that vision of the SINAEB, ... the [recently proposed] National Evaluation System of Basic Education which was a painful process [for Campanha] ... with a big effort of [Campanha] ... but Todos pela Educação emerged within that framework of [large-scale] evaluation.

(BR-NNGO-04)

Privately funded foundations are part of the new but vibrant Brazilian civil society. They are important elements of QAE networks. Besides exerting their influence through Campanha and TPE, they also have a voice of their own and occupy an important place in the political arena. Nationally, they influence agenda- setting through knowledge production, vigorous networking, and media influence:

[An] important group that has organised itself recently are the foundations of major corporate groups... They are groups based on a vision of demanding results. They have organised themselves to say "Look, we have to have the children finishing elementary education." ... This group has grown ... It plays an important role and is very present in the media.

$(\mathrm{BR}-\mathrm{N}-03)$

At the sub-national level, privately funded foundations influence local government projects through their technical and financial capacity. These foundations can gather various domestic and foreign sponsors and IGO funding under national projects channelled to schools and individuals, the details of which are published on their websites. IGOs acknowledge the foundations' strength and engage actively with them:

And in Brazil most of the research I'm doing is with foundations like the Lemann Foundation and the Instituto Unibanco in São Paulo. The Ayrton Senna Foundation too. I mean, there are some which have really good people who know education and provide a lot of technical help to the states and municipalities.

(BR-IGO-05)

A need for quality expertise was the catalyst in the establishment of the Brazilian Association of Educational Evaluation (ABAVE). The scholars involved found it difficult to access the main academic forums and were constantly struggling to convey the importance and meaning of the quantitative approach and its tools. Founded in 2003, the association has gained enormous influence on QAE policy and practice:

[In Brazil] we had the National Association of [Graduate Studies and] Research in Education [now the ANPEd]. At some stage that Association split because a group of scholars [who were at the genesis of the 
large-scale assessments] could not find a way to engage in dialogue within an association of education researchers with a broad focus on the Faculties of Education ... which are resistant to this framework. So, the spilt was a demonstration, and today ABAVE ... is one of the organisations with which ... [the INEP] dialogue[s] a lot.

$(\mathrm{BR}-\mathrm{N}-01)$

In Brazil, the QAE actor constellation has consisted not only of state actors but also third-sector organisations and movements. Indeed, the QAE agenda in Brazil has stimulated actors' traditional roles and resulted in the heavy involvement of the third sector and business interests.

\section{China: "scholars doing scholars' work"?}

The creation of the national QAE system in China has given room for action to existing actors and given rise to new ones. First, the construction of the assessment system has transferred power to sub-national education bureaus in relation to their corresponding financial bureaus. Under the communist party-state system, education, like other politicised spheres, is based on long-term planning, and it is the ministerial staff who are tasked with policymaking. High-ranking officers in the ministries have had much say in how things are done. However, although policies are decided at national and provincial levels, where funding and policy implementation are concerned, the regions themselves have considerably more responsibility (Postiglione 2011; Qi 2011). Many of our interviewees identified a trend towards such policymaking decentralisation. More important, this was also the case where monitoring and assessing quality in education were concerned:

$[\mathrm{W}]$ hen it comes to basic education [i.e., the nine-year compulsory education system] quality monitoring in China, we have come up with a saying: "make counties the system of basic education quality assurance". This means that wherever you go, the county level carries out basic education quality management and control. Province and national level governments will formulate macro-level supervision policies, but the concrete executive units are the counties.

(CN-E-13)

As national assessments have started providing feedback to the localities, the local educational bureaus, as one interviewee pointed out, have used it as evidence when they have confronted the financial departments at corresponding levels and demanded resources to tackle the problems they have identified.

Second, and perhaps more important, a notable change in actor relations has come with the emergence of actors which are considerably more independent of the party-state's control than previously. In QAE policymaking, these developments have manifested themselves in two ways. As has been mentioned, 
both IGOs and INGOs are consulted in the policymaking process, especially when the government is addressing what it considers more marginal issues in its reforms plans. In addition to direct consultation, the staff working for these organisations suggested when interviewed that it is hoped that decision-makers themselves will learn from their initiatives. The logic is that policymakers either observe from a distance how projects are faring or that the localities themselves or the media pass the information upwards. The INGOs also seek to engage directly with staff from domestic NGOs, as well as practitioners and academics from the government system whom they perceive as influential. Despite this, the organisations' personnel acknowledge that their influence on policy is somewhat limited, except perhaps where changes in practice in the localities in which they are directly working with education issues are concerned.

However, the construction of the national QAE system has made data experts more politically relevant. First, provincial institutes of education research have been established. These researchers are tasked with researching education issues and submit their work to the corresponding executive departments to assist in policymaking. Second, the Ministry of Education has established "national bases" in universities; these are essentially think tanks tasked with, as one interviewee (CN-E-05) put it, the "study of policy and study for policy". The staff working at these bases are academics, and many naturally have extensive international experience. Because of the traditional emphasis on ranking, much attention has been paid to the OECD's PISA rankings, and the different nations' PISA success propels research interest towards certain education regimes. These universities have also established designated branches to research international organisations which have strengthened their links with IGOs like the World Bank, UNESCO, and the OECD. However, it is noteworthy that the Ministry of Education's bureaucracy does not explicitly bias research foci towards certain national systems or research topics. Institutes of education research and university-based think tanks produce research data on international organisations and assessment practices, which are then utilised to assist in decision-making when policies are formulated. A member (CN-E-07) of such a think tank explained, "As a matter of fact our unit is a think tank of the state's Ministry of Education. That means that every time they introduce a policy, we need to do research." Although these expert institutions cannot operate entirely independently of the party-state, their staff consists of academics rather than bureaucrats or party functionaries. This emergence of a semi-state approach represents a major departure from the days when the Ministry of Education was in absolute control: "Many people in the Ministry of Education now say that scholars should do scholars' work, administrators should do administrators' work" (CN-E-02). However, despite ambition to change the situation, the influence of scholars on policy is still somewhat marginal. One interviewee complained,

[W] hen formulating Chinese national policies and school policies, the whole process from formulation to implementation is closed. In recent years it has become more open, but despite this, many scholars' viewpoints 
hardly ever become policy in practice. The state is vigorously pushing forward this aspect [of including scholars' perspectives].

(CN-E-13)

Indeed, the model of policymaking involving prominent individuals within the ministry is still dominant, and policymakers rarely have the inclination or time to engage deeply with academics and experts. Consequently, communication between the groups is often limited to very short policy recommendation briefings.

All in all, and much in line with the technocratic tendencies at play in wider Chinese society, normative power has been transferred from party-state functionaries to academics, whose professional networks and research foci position them firmly within a transnational network. As our analytical framework suggests, this reveals the changes QAE has made to the actor constellation: where the question of who participates in defining and assessing quality is concerned, emerging actors are challenging the existing status quo. An interviewee draws an interesting parallel with Chinese education reforms, in which relevance also equates to financial gain:

These things [reforms of the QAE system] benefit certain people. Actually, it is not just education, but in other aspects the deep reforms in China touch certain interests. But these reforms have to be made and there is no other option. If not, there is no development ... If we take the reform of China's state-owned enterprises as an example, they were all monopolies before. Communications and petroleum [industries], for example, were all monopolies. And monopolies do not have competition, and without competition the results will always be very poor. If the state's inputs were very big, it was possible that the profits were also very high, but all these profits were made by monopolies. So, these state-owned enterprises were reformed by dragging them into a system of competition. But this of course did not go well with some people, because previously they were able to make a lot of money, and this changed when private enterprises came into the picture. Other people took their slice of the cake. This is also the case with education.

(CN-S-01)

Such an approach indicates, implicitly at least, that relevance is not - and should not be - only a top-down decision, but different actors' perception of quality (and how it should be assessed) should compete for relevance in the QAE field.

\section{Russia: state-dependent $\mathrm{Q} A E$}

Compared with Brazil, Russian QAE reforms and agenda-setting are more state-driven and in this sense closer to the Chinese constellation. Where the agenda is concerned, the recent change in Russia has been significant. Previously, 
Russia only had one standardised test at the end of grade 11 (the Unified State Exam, USE), which became compulsory throughout the country in 2009. The USE is both a school graduation and university entrance examination. Alongside more general education statistics, the scores of the USE have constituted a key source of information for national system evaluation and evidence-based policymaking. The Russian federal authorities are now seeking to reinstate a "uniform educational space" for education. This entails the introduction of new federal curricular guidelines which define the expected learning results and development of more diverse QAE procedures initiated by the national authorities.

The federal level has introduced another standardised graduation examination after grade 9 (at the end of lower secondary, or basic, education). A samplebased National Study of Education Quality (NIKO) was also initiated in 2014 with a focus on primary and secondary school subjects and their respective skills. It was introduced with the intention of grasping how children are taught in different parts of the country to identify problematic areas and best practices and to compile nationwide education statistics. The federal authorities particularly emphasise the difference between NIKO and the high-stakes USE, maintaining that the former poses no risk to the students and schools assessed in the survey. Since 2015, the federal level has also started to administer the All-Russia Examinations, now being piloted and planned as part of the overall evaluation system in the near future. They test end-of-school-year learning results annually, and these are said to provide information on learning achievements for school, local, and federal actors.

These different data sources form the basis of a large annual report about the state of the education system, prepared by a department of the federal ministry. The first such report was published in 2015 and based on information collected in 2014:

Well, this is a bit of an analogy to what in some countries is called a national report on the system of education. We had nothing like that [for about 10 years]. We only collected statistics in one way or another, and they were utilised locally somewhere for developing some local projects. But from last year [2015] it became a systematic process, and we write a serious report about all levels of education on the basis of statistical data, data we receive from the federal units on the basis of a particular plan of the characteristics of the system. It is not only a statistical database, but also an analytical database that detects some trends, some problematic areas, and some serious changes affected by the decisions taken earlier.

(RU-N-03)

It is clear from our interview materials that it is planned to make the collection of data about the education system more detailed and systematic, which will have further effects on the actor constellation. When our interviews were conducted, the federal ministry was in the process of establishing a blueprint for how 
the different sources of information would feed into national decision-making. Indeed, the federal government is the main architect in designing changes to the QAE organisations. The recently established Federal Institute of Education Quality Evaluation is intended to become a centre for data accumulation and processing under the auspices of the Federal Service for Supervision in Education and Science, which means the Federal Ministry of Education and Science is its superior. Moreover, the federal level is dissatisfied with the quality of information it receives and is seeking to establish a system that will help obtain more detailed knowledge of schools:

[T] he subjects of the Russian Federation are in charge of collecting schoollevel data, so that it is aggregated on the level of the federal subjects and presented this way to the ministry. So, this means that we don't see the construction inside the school. This is the first problem and we are aware of it, so from January we will introduce a system that will enable us to establish an infrastructure for, from next autumn and winter, gaining information about each school.

(RU-N-03)

The developments just described signal a strong desire for a nationally anchored centralised and standardised education evaluation system. This entails increasingly centralised data collection and analysis by actors accountable to and financed by the national authorities. At the same time, expert networks also play an important role in Russia. The predecessors of the USE and the structures administering them were small-scale commercial organisations and research groups interested in standardised testing. They learned the craft of standardised testing from available international sources because of their personal or commercial interest, aided by their prior training in mathematics and psychology, for example. The historical roots of the two ministerial units now running the USE for grades 11 and 9 are in the early post-Soviet practice of voluntary standardised testing of university applicants. These skills and wider experience were utilised when standardised assessments became a federal initiative, promoting experts with the required skills to the higher ranks of the newly established federal structures.

An equally important and partly connected group of evaluation experts began developing their evaluation proficiency in direct connection with the international tests in which Russia had first participated - TIMSS in 1995 and PISA and PIRLS in the early 2000s. These experts later performed important roles as test developers and analysts in the USE. However, as the following quotations demonstrate, they did not take the transfer of foreign expertise for granted, and they quickly developed their own capacity:

Then we started, ... this is the very first point [to consider], ... what can and cannot be transferred. We learned ... how to do it - we even invited specialists from the Netherlands who developed PISA 2003. They held a 
wonderful seminar. Almost all the subject specialists who write test items for the USE took part in the seminar. It was great, interesting, but we could not utilise the test tasks themselves.

(RU-E-12)

We knew the state of affairs in Russia. Unfortunately, there were situations when our colleagues, especially Americans, thought that we had just jumped off a branch of a tree ... Nevertheless, of course, we learned something, and what we told them about what we have done was interesting for them too.

(RU-E-10)

Overall, links between national and international experts are highly appreciated, which also means that policy transfer has occurred through professional interactions the Russian actors for the most part perceive as normal mutual learning and professional communication. Testing expertise has been the most significant lesson:

You understand, the instrument is very new for this sphere. And we would not have created it had the Bank not attracted an excellent consultant ... Without [this person] we would not have created the instrument: [he/she] is the ideologue behind everything, and through [him/her] all this knowledge, skills and competences in creating test items, processing of results, the approaches and methods we use in the developing of the tasks and the assessment scale, all of this is due to the correct scientific advice of [the consultant], no doubt.

(RU-E-07)

Many if not most of these Russian experts have stayed with the organisations running standardised assessments and quality evaluation by circulating within and between different organisations and blurring their identities as civil servants or academics at different phases of their careers. Overall, while in Russia the rise of QAE has made expertise and the individuals possessing it more significant, the demand for education quality assessment and data production has not led to the emergence of structures independent of the national authorities. Instead, national policies and goals permeate all the new establishments, even if their functioning was initially enabled by and relied on the expertise of qualified persons located outside the ministerial apparatus and connected with transnational professional networks.

\section{Conclusion: a transnational expert community}

In the preceding examples, the most dramatic changes in actor constellations after the introduction of QAE agendas happened in Brazil, where we observe a fundamental change of thinking concerning which actors are relevant in 
education policy. In the Chinese and Russian cases, the state authority has maintained a tighter grip on what is happening in the field of QAE in education. Baumgartner and Jones (2009) suggest the main vehicle for change is positive, change-supporting feedback. In Brazil, the state does not exert tight control over QAE policy, as there are many third-sector movements contributing to the agenda. The feedback provided by Brazilian civic movements would not be possible in the state-controlled systems of China and Russia. In China, for example, the results of large-scale evaluations are not disclosed to the public, which does not encourage the demand for improvement in schools' quality. However, we do observe a change of agenda, effected by international organisations and the state-led creation of the QAE expert community.

This chapter also indicates the way in which the case countries were able to develop more QAE capacity during the 1990s and early 2000s. This enhanced data infrastructure and expertise have made national governments less dependent on international organisations, but they have also remained interested in international trends. Despite the bigger picture of the state retaining control of QAE in China and Russia, all our cases have seen change. Brazilian subnational actors, as opposed to national actors, now work with international organisations and their loans. The QAE infrastructure has also allowed civic movements to play a more active role in education. In China, some semigovernmental organisations, such as think tanks, have become more significant as QAE has gained in importance. In Russia, room for action is largely reserved for national agencies and their various tests. However, expert networks play a role in channelling external influence. The role of international actors has changed in all contexts, and in all cases, the countries themselves have been able to direct their influence.

In the analysed cases, there are clear differences in how the transnational QAE agenda has affected national polity. However, a common dynamic is involved in how transnationalism becomes embedded in expert communities. Although the attitude towards international advice has historically varied between and within each country, expert networks are increasing the transnational information flows. This change has occurred gradually, but it is visible in each context. This transnational embeddedness is also supported by the fact that international organisations have sought to intensify their sub-national operations in Brazil. In Russia, the international organisations' operations were largely sub-national during the early post-Soviet period, but their overall role has since been significantly reduced, including at the sub-national level. In each case, the change of agenda has been connected to a change in actor constellations.

\section{Bibliography}

Altbach, P. G. (1991). Trends in comparative education. Comparative Education Review, 35(3), 491-507.

Ball, S. J. (1993). What is policy? Text, trajectories and toolboxes. Discourse, 13(2), 10-17.

Baumgartner, F. R., \& Jones, B. D. (2009). Agendas and Instability in American Politics (2nd ed.). Chicago, IL: Chicago University Press. 
Centeno,V. G., Kauko, J., \& Candido, H. H. (2017). Quality assurance and evaluation through Brazilian lenses: An exploration into the validity of umbrella concepts. Comparative Education 54(2), 132-158.

Cheng, H., Gutierrez, M., Mahajan, A., Shachmurove, Y., \& Shahrokhi, M. (2007). A future global economy to be built by BRICs. Global Finance Journal, 18, 143-156.

Cohen, M. D., March, J. G., \& Olsen, J. P. (1972). A garbage can model of organizational choice. Administrative Science Quarterly, 17(1), 1-25.

Cooper, J. (2006). Of BRICs and brains: Comparing Russia with China, India, and other populous emerging economies. Eurasian Geography and Economics, 47(3), 255-284.

Dahler-Larsen, P. (2011). Afterword. In J. Ozga, P. Dahler-Larsen, C. Segerholm, \& H. Simola (Eds.), Fabricating Quality in Education: Data and Governance in Europe (pp. 151-159). London: Routledge.

Deng, G. (2010). The hidden rules governing China's unregistered NGOs: Management and consequences. The China Review, 10(1), 183-206.

Dente, B. (2014). Understanding Policy Decisions. Cham, Heidelberg, New York, Dordrecht, \& London: Springer International Publishing.

Fernando, L. S. (2002). Theoretical approach to decentralization: An introduction. Journal of Management Science, 1(1\&2), 117-141.

Glosny, M. A. (2010). China and the BRICs: A real (but limited) partnership in a unipolar world. Polity, 42(1), 100-129.

Gu, M. (2010). A blueprint for educational development in China: A review of "The National Guidelines for Medium- and Long-Term Educational Reform and Development (2010-2020)". Frontiers of Education in China, 5(3), 291-309.

Held, D., McGrew, A., Goldblatt, D., \& Perraton, J. (1999). Global Transformations: Politics, Economics and Culture. Stanford: Stanford University Press.

Hsia, R.-J., \& White, L. T., III. (2002). Working amid corporatism and confusion: Foreign NGOs in China. Nonprofit and Voluntary Sector Quarterly, 31(3), 329-351.

Jacobs, L. M., \& Van Rossem, R. (2014). The BRIC phantom: A comparative analysis of the BRICs as a category of rising powers. Journal of Policy Modelling, 36S, S48-S66.

Kauko, J., Centeno, V. G., Candido, H., Shiroma, E., \& Klutas, A. (2016). The emergence of quality assessment in Brazilian basic education. European Educational Research Journal 15(5), $558-579$.

Kent, A. (2002). China's international socialization: The role of international organizations. Global Governance, 8(3), 343-364.

Kingdon, J. W. (2003). Agendas, Alternatives, and Public Policies (2nd ed.). New York, NY: Longman.

Kipnis, A. (2006). Suzhi: A keyword approach. The China Quarterly, 186, 295-313.

Leonteva, M., Plomp, T., \& Voogt, J. (1998). Examination practices in the Russian Federation present situation and perspectives for development. In J. Voogt \& T. Plomp (Eds.), Education Standards and Assessment in the Russian Federation - Results From Russian-Dutch Cooperation in Education. Leuven: Acco.

Luhmann, N. (2002). Die Politik der Gesellschaft. Frankfurt am Main: Suhrkamp.

Ma, Q. (2002). The governance of NGOs in China since 1978: How much autonomy? Nonprofit and Voluntary Sector Quarterly, 31(3), 305-328.

Ngok, K., \& Kwong, J. (2003). Globalization and educational restructuring in China. In K. Mok \& A. Welch (Eds.), Globalization and Educational Restructuring in the Asia Pacific Region (pp.160-188). Houndmills, Basingstoke, Hampshire, \& New York, NY: Palgrave Macmillan. OECD. (1998). Review of National Policies for Education - the Russian Federation. Paris: OECD. Ozga, J. (2012). Knowledge stocks and flows. Data and education governance. In T. Fenwick, \& L. Farrell, (Eds.) Knowledge Mobilization and Educational Research: Politics, Languages and Responsibilities. London: Routledge. 
Ozga, J., Dahler-Larsen, P., Segerholm, C., \& Simola, H. (2011). Introduction. In J. Ozga, P. Dahler-Larsen, C. Segerholm, \& H. Simola (Eds.), Fabricating Quality in Education: Data and Governance in Europe (pp. 1-8). London: Routledge.

Palonen, K. (1993). Introduction: From policy and polity to politicking and politicization. In K. Palonen, T. Parvikko, K. Palonen, \& T. Parvikko (Eds.), Reading the Political: Exploring the Margins of Politics (pp. 6-16). Helsinki: Finnish Political Science Association.

Palonen, K. (2003). Four times of politics: Policy, polity, politicking, and politicization. Alternatives, 28(2), 171-186.

Pant, H. V. (2013). The BRICS fallacy. The Washington Quarterly, 36(3), 91-105.

Postiglione, G. A. (2011). Education. In X. Zang (Ed.), Understanding Chinese Society (pp. 80-95). London \& New York, NY: Routledge.

Qi, T. (2011). Moving toward decentralization? Changing education governance in China after 1985. In T. Huang \& A. W. Wiseman (Eds.), International Perspectives on Education and Society Book Series, Vol. 15, The Impact and Transformation of Education (pp. 19-41). Bingley: Emerald Group Publishing Limited.

Robertson, S. L., Bonal, X., \& Dale, R. (2002). GATS and the education service industry: The politics of scale and global reterritorialization. Comparative Education Review, 46(4), 472-495.

Rondinelli, D. (1981). Government decentralization in comparative perspective: Theory and practice in developing countries. International Review of Administrative Science, 47(2), 133-145.

Sabatier, P. A., \& Jenkins-Smith, H. C. (1999). The advocacy coalition framework: An assessment. In P. A. Sabatier (Eds.), Theories of the Policy Process (pp. 117-166). Boulder, CO: Westview Press.

Scharpf, F. W. (1997). Games Real Actors Play: Actor-Centered Institutionalism in Policy Research. Boulder, CO: Westview Press.

Schmitt, C. (1991). Der Begriff des Politischen. Berlin: Duncker \& Humblot.

Simola, H., Rinne, R., Varjo, J., \& Kauko, J. (2013). The paradox of the education race: How to win the ranking game by sailing to headwind. Journal of Education Policy, 28(5), 612-633.

Suominen, O., Kallo, J., Rinne, R., \& Fan, Y. (2017). Subtle convergence? Locating similarities between Chinese educational reforms and global quality assurance and evaluation trends. Quality Assurance in Education, 25(2), 146-160.

Vedung, E. (2003). Arviointiaalto ja sen liikkeelle panevat voimat [The Wave of Evaluation and the Forces Moving It]. Stakes, FinSoc Työpapereita 2/2003. Helsinki: Stakes.

Werner, M., \& Zimmermann, B. (2006). Beyond comparison: "Histoire Croisée" and the challenge of reflexivity. History and Theory, 45(1), 30-50.

World Bank. (1995). Russia - Education in the Transition. Washington, DC: World Bank.

World Bank. (2007). Implementation completion and results report for the education reform project (Report No. !CR0000303). Retrieved from http://documents.worldbank.org/curated/ en/993451468144562534/Russian-Federation-Education-Reform-Project

World Bank. (2016, January 29). Projects/Brazil. Retrieved from www.worldbank.org/ projects $/$ search?lang $=$ en\&searchTerm $=\&$ countrycode_exact $=B R$

Yang, G. (2005). Environmental NGOs and institutional dynamics in China. The China Quarterly, 181, 46-66.

Yang, R. (2009). International organizations and Asian higher education: The case of China. In R. Malee Bassett \& A. Maldonado-Maldonado (Eds.), International Organizations and Higher Education Policy: Thinking Globally, Acting Locally? (pp. 174-191). New York, NY \& London: Routledge.

Yin, D. (2009). China's attitude toward foreign NGOs. Washington University Global Studies Law Review, 8(3), 521-543.

Zhang, H., \& Wan, D. (2017). Status of Chinese science education reforms: Policies and development framework. In L. L. Liang, X. Liu, \& G. W. Fulmer (Eds.), Chinese science education in the 21st century: Policy, practice and research (pp. 5-30). Dordrecht: Springer. 